Vol. 1 No. 3 Desember 2021 e-ISSN : 2797-3344 P-ISSN : 2797-3336

\title{
MENINGKATKAN PRESTASI BELAJAR IPA MELALUI PENERAPAN METODE ROUND TABLE PADA SISWA KELAS VII D SMPN 2 PRINGGABAYA MASA PANDEMI COVID-19 TAHUN PELAJARAN 2021/2022
}

\author{
NI MADE SULADI \\ SMP Negeri 2 Pringgabaya, Lombok Timur \\ nimade.suladi@gmail.com
}

\begin{abstract}
ABSTRAK
Pendekatan pembelajaran dengan metode round table merupakan konsep belajar yang membantu guru mengaitkan antara materi yang diajarkan dengan situasi dunia nyata siswa dan mendorong siswa membuat hubungan antara pengetahuan yang dimilikinya dengan penerapannya dalam kehidupan mereka sebagai anggota keluarga dan masyarakat. Dengan konsep itu, hasil pembelajaran diharapkan lebih bermakna bagi siswa. Proses pembelajaran berlangsung alamiah dalam bentuk kegiatan siswa bekerja dan mengalami, bukan mentransfer pengetahuan dari guru ke siswa. Strategi pembelajaran lebih dipentingkan daripada hasil. Tujuan dari penelitian tindakan kelas (PTK) ini adalah untuk mengetahui sejauh mana peningkatkan prestasi belajar siswa pelajaran IPA dengan menerapkan Metode Round Table. Dalam penelitian tindakan kelas (PTK) ini dilakukan dalam 2 siklus, dari hasil tindakan yang dilakukan terbukti dapat meningkatkan Prestasi belajar siswa dengan mencapai standar ideal. Dari 66,7 \% pada siklus I, dapat meningkat pada siklus VI menjadi 86,67 \%. Hasil penelitian tindakan ini menunjukkan bahwa penerapan pembelajaran dengan Metode Round Table dapat meningkatkan ketuntasan belajar siswa pada pelajaran IPA dengan ketuntasan mencapai 86,67 $\%$.
\end{abstract}

Kata Kunci: prestasi belajar, metode round table

\section{ABSTRACT}

The learning approach using the round table method is a learning concept that helps teachers relate the material being taught to students' real-world situations and encourages students to make connections between their knowledge and its application in their lives as family and community members. With this concept, learning outcomes are expected to be more meaningful for students. The learning process takes place naturally in the form of student activities working and experiencing, not transferring knowledge from teacher to student. A learning strategy is far more important than a result. The purpose of this classroom action research (CAR) is to determine the extent to which students' learning achievement in science has been increased by applying the Round Table method. In this classroom action research (CAR), it is carried out in 2 cycles, from the results of the actions taken it is proven to be able to improve student learning achievement by achieving ideal standards. From $66.7 \%$ in the first cycle, it can increase in the VI cycle to $86.67 \%$. The results of this action research indicate that the application of learning with the Round Table Method can improve student learning mastery in science lessons with completeness reaching $86.67 \%$.

Keywords: learning achievement, round table method

\section{PENDAHULUAN}

Berdasarkan pada amanat UUD 1945, Pendidikan adalah: merupakan upaya untuk mencerdaskan kehidupan bangsa yang bertaqwa, cinta dan bangga terhadap bangsa dan negara, terampil, kreatif, berbudi pekerti yang santun serta mampu menyelasaikan permasalahan di lingkungannya. Proses pembelajaran bukan hanya dilakukan di kelas saja akan tetapi di luar kelaspun juga termasuk kedalam kegiatan pembelajaran. Hakekat pembelajaran sains IPA (Ilmu Pengetahuan Alam) didefinisikan sebagai pengetahuan yang diperoleh melalui pengumpulan data dengan eksperimen, pengamatan, dan deduksi untuk menghasilkan suatu penjelasan tentang sebuah gejala yang dapat dipercaya. 
Tujuan Pendidikan Nasional menurut Undang-undang No. 20 Tahun 2003 Pendidikan adalah usaha sadar dan terencana yang tertuang dalam tujuan Pendidikan Nasional dan pendidikan sekolah dasar yaitu untuk mewujudkan suasana belajar dan proses kegiatan pembelajaran dengan tujuan agar siswa secara aktif mengembangkan potensi dirinya untuk memiliki kekuatan spiritual keagamaan, pengendalian diri, kepribadian, kecerdasan, akhlak mulia, serta keterampilan yang diperlukan dirinya dan dalam berbangsa dan bernegara. Pendidikan yang dimiliki oleh manusia dewasa dipergunakan untuk membimbing manusia yang belum dewasa menuju kedewasaannya. Artinya manusia dewasa memberikan bantuan kepada manusia yang belum dewasa dalam memecahkan kesukaran-kesukaran dialami dan memberikan bantuan yang dapat menyadarkan orang itu akan kepribadiannya sendiri sehingga dengan demikian ia sanggup memecahkan persoalan-persoalan yang dihadapinya.

Menurut Martino Jan Lengeveld: bahwa pengertian pendidikan adalah upaya menolong anak untuk melakukan tugas hidupnya secara mandiri supaya dapat bertanggungjawab secara susila. Pendidikan merupakan usaha manusia dewasa dalam membimbing manusia yang belum dewasa menuju kedewasaannya.

Menurut Stella Van Petten Henderson: bahwa pendidikan adalah kombinasi pertumbuhan dan perkembangan diri dan warisan social .Pendidikan merupakan kebutuhan yang sangat mendasar bagi setiap manusia untuk kelangsungan hidupnya sebagai anggota masyarakat. Jadi pendidikan adalah usaha sadar yang dilakukan oleh manusia untuk menggapai keselamatan dan kebahagiaan di dunia dan akhirat dengan kata lain kebahagiaan jasmani dan rohani. Berdasarkan pendapat para ahli diatas yang sesuai degan kenyataan di sekolah bahwa pendidikan itu kombinasi antara tumbuh kembangnya siswa dengan warisan sosial dalam masyarakat sehingga apabila keduanya dijalankan seyogyanya program pendidikan menjadi lebih baik.

Carin dan Sund (1993) dalam Puskur-Depdiknas (2006) mendefinisikan IPA sebagai "pengetahuan yang sistematis dan tersusun secara teratur, berlaku umum (universal), dan berupa kumpulan data hasil observasi dan eksperimen". Dalam melaksanakan proses pembelajaran pada mata pelajaran IPA Terpadu Kelas VII D SMPN 2 Pringgabaya ternyata peneliti banyak menjumpai permasalahan antara lain: hasil belajar IPA masih rendah, siswa kurang memperhatikan saat guru menjelaskan dan siswa kurang termotivasi untuk belajar

Salah satu indikator pendidikan berkualitas adalah prolehan belajar siswa, baik itu hasil belajar dalam bentuk kognitif, afektif, psikomotor. Hasil belajar siswa sangat di pengaruhi oleh kegiatan proses belajar mengajar. Sadia (2002: 6) mengungkapkan factor-faktor yang mempengaruhi kegaiatan proses belajar mengajar adalah pertama, Instrumen Input yaitu, kurikulum, perpustakaan, guru dan sebagainya, kedua, Rau Imput yaitu, siswa, prestasi, cara belajar dan sebagainya, ketiga, Enviromental Input yaitu, lingkungan fisik dan sosial budaya. Dari ketiga faktor utama yang mempengaruhi lancar tidaknya proses pembelajaran tersebut di atas, dalam penelitian ini di fokuskan pada usaha pembelajaran yang dilakuka oleh guru di dalam kelas, karena keberhasilan pembelajaran dalam arti tercapainya tujuan-tujuan instruksional sebagian besar sangat bergantung pada kemampun guru. Hal tersebut sesuai dengan penelitian Sudjana (2000) bahwa: 76,6 hasi lbelajar siswa dipengaruhi oleh kompetensi guru. Dengan rincian kemampuan guru mengajar/mengelola proses pembelajaran memberikan sumbangan $32,43 \%$ dan sikap guru terhadap mata pelajaran $8,60 \%$.

Adanya virus covid-19 pada tahun 2019 memberikan dampak yang luar biasa hampir pada semua bidang, salah satunya pada bidang pendidikan. Dengan adanya virus covid-19 ini membuat proses pembelajaran menjadi berubah, tetapi dalam keadaan seperti ini pun guru masih tetap harus melaksanakan kewajibanya sebagai pengajar, dimana guru harus memastikan siswa dapat memperoleh informasi/ilmu pengetahuan untuk diberikan kepada siswa. Sehingga guru pun dituntut untuk memberikan inovasi terbaru.

Dari kebiasaan berinteraksi secara langsung dengan peserta didik mempraktekkan segala sesuatu di depan anak, mendampingi cara melakukan segala aktifitas yang membutuhkan sentuhan fisik antara guru dan peserta didik, semua harus berubah dilakukan secara daring yang 
nota bene anak pedesaan tidak seharusnya menggunakan media HP karena seorang anak harus dapat bersosialisasi dengan dunia luar tidak dibiasakan dengan HP.

Kendala inilah yang awal terjadi pada guru dan siswa, terutama di daerah pedesaan, dimana HP yang memiliki adalah orang tuanya, sedangkan orang tuanya kebanyakan ibu mereka bekerja sebagai buruh tani yang berangkat pagi buta pulang menjelang sore atau ayahnya tukang bangunan yang merantau di daerah lain sehingga tidak setiap waktu pulang ke rumah, anak di rumah tinggal dengan kakek dan neneknya.

Dari sini jelas terlihat kesulitan ketika guru melakukan pembelajaran secara daring melalui group Whatshapp yang membaca adalah orang tua mereka yang sedang bekerja, akhirnya tugas tidak tersampaikan kepada anak, ketika pulang orang tua sudah dalam keadaan lelah sehingga tidak dapat mendampingi anak untuk melakukan tugas yang diberikan guru secara daring. Apalagi jika guru memberikan tugas yang membutuhkan media pembelajaran berupa berbagai macam benda - benda yang harus dicari oleh anak, akan sangat terbebani orang tua murid. Untuk membentuk proses pembelajaran yang sangat efektif yang bersesuaian dengan kondisi pandemi. Untuk menyiasati kondisi ini, Cara/tehnik luring bisa dijadikan salah satu alternative yang cukup efektif.

Untuk meningkatkan prestasi siswa SMPN 2 Pringgabaya pada mata pelajaran IPA kelas VII D maka guru menggunakan model atau pendekatan pembelajarn kelompok (kooperatif) yang menitik beratkan pada keaktifan siswa dan berorientasi pada siswa. Diantara model pembelajaran kooperatif yang lebih banyak melibatkan keikut sertaan siswa dalam proses pembelajaran adalah dengan metode round table.

Pembelajaran kooperatif dengan metode round table merupakan pembelajaran dengan pendekatan model kooperatif atau berkelompok yang dapat memancing siswa untuk belajar, serta dapat melatih komunikasi social siswa baik dalam maupun di luar lingkungan sekolah. Oleh karena itu, proses belajar mengajar akan lebih aktif jika menggunkan pendekatan model pembelajaran kooperatif round table. Dalam metode kooperatif round table semua siswa dalam kelompok berusaha memahami dan menguasai materi yang akan diajarkan dan selalu aktif kerja kelompok, sehingga saat giliran masing-masing kelompok mendiskusikan materi yang diperoleh, mereka dapa tmenjelaskan satu atau dua buah kalimat pada selembar kertas secara bergantian dalam kelompok kemudian kalimat tersebut menjadi sebuah deskripsi artinya, materi yang telah dibaca atau dipelajari oleh siswa akan diperaktikkan baik secara lisan maupun tulisan karena menurut Robert (1988) sering memperaktikkan materi pelajaran akan lebih mudah memanggil kembali memori lama yang berhubungan dengan materi sedang ditekuni, karena kita belajar 70\% dari apa yang kita katakan, 90\% dari apa yang kita lakukan, sehingga ingatan siswa lebih kuat dibandingkan dengan hanya mendengarkan saja. Selain itu juga metode round table mendidik siswa untuk mengembangkan kecakapan berkomunikasi dan mengembangkan kemampuan bekerja sama.Pada pembelajaran kooperatif round table dikembangkan dua kemampuan berkomunikasi baik lisan maupun tulisan, Karena menyampaikan gagasan baik tulisan maupun lisan memerlukan keberanian.Keberanian seperti itu dipengaruhi oleh keyakinan diri dalam aspek kesadaran diri, oleh karena itu perpaduan antara keyakinan dan kemampuan berkomunikasi akan menjadi modal berharga bagi seseorang untuk berkomunikasi dengan orang lain, maka perlu dikembangkan sejak dini agar siswa tidak merasa takut didalam menyampaikan gagasan atau pendapatnya kepada orang lain sehingga tidak mengalami jalan buntu, apalagi dalam proses pembelajaran atau dalam menghadapi dunia nyata. Kemampuan berkomunikasi secara lisan pada saat mempersentasikan materi yang didiskusikan mereka dapat mempertanggungjawabkan jawabannya. Dengan demikian siswa akan termotivasi untuk berperan aktif dalam proses belajar mengajar. Atas alasan yang telah dikemukakan di atas, maka penulis berkeinginan untuk mengadakan suatu penelitian tindakan kelas dengan judul "Meningkatkan Prestasi Belajar IPA Melalui Penerapan Metode Round Table Pada Siswa Kelas VII D SMPN 2 Pringgabaya Masa Pandemi Covid-19 Tahun Pelajaran 2021/2022". 


\section{METODE PENELITIAN}

Jenis penelitian ini adalah penelitian tindakan kelas (PTK). Penelitian tindakan kelas (PTK) merupakan suatu proses investigasi terkendali yang berdaur ulang dan bersifat reflektif mandiri yang dilakukan oleh guru yang memiliki tujuan untuk melakukan perbaikan-perbaikan terhadap sistem, cara kerja, proses, isi, kompetensi, atau situasi pembelajaran. Penelitian tindakan ini dilaksanakan pada semester ganjil tahun pelajaran 2021/2022.

Penelitian ini dilaksanakan di kelas VII D SMP Negeri 2 Pringgabaya Kabupaten Lombok Timur Tahun Pelajaran 2021/2022.Lokasi sekolah berada di pinggir jalan utama dengan akses jalan beraspal dan dekat dengan pemukiman penduduk. SMP Negeri 2 Pringgabaya mempunyai seorang kepala sekolah, tenaga pendidik 45 orang dan 12 orang tenaga non kependidikan. Dari 45 orang tenaga pendidik tersebut, 21 orang adalah Aparatur Sipil Negara (ASN) dan 24 orang Guru Tidak Tetap (GTT). Pada tahun pelajaran 2021/2022 ini memiliki siswa mulai dari kelas 7 sampai dengan kelas 9. Siswa kelas 7 berjumlah 188 orang, kelas 8 berjumlah 219 orang dan kelas 9 berjumlah 201 orang.

Penelitian ini dilaksanakan dengan menggunakan dua siklus, dengan setiap siklusnya dilaksanakan 2 kali pertemuan. Penelitian ini dilaksanakan selama kurang lebih tiga bulan, yaitu mulai bulan Juli sampai dengan bulan September 2021. Adapun subyek penelitiannya adalah siswa kelas VII D di SMP Negeri 2 Pringgabaya pada semester gasal tahun pelajaran 2021/2022 dengan melibatkan 31 siswa, yang terdiri dari 16 siswa laki-laki dan 15 siswa perempuan dengan usia rata-rata 14 tahun.

Pada penelitian ini menggunakan prosedur berupa siklus-siklus.Pada penelitian tindakan kelas ini, memiliki ciri utama yaitu terdapat siklus-siklus yang tiap siklusnya memiliki tahapan-tahapan yaitu : a) perencanaan tindakan (planning), b) tindakan (acting), c) pengamatan (observasing), d) refleksi (reflecting). Desain penelitian tindakan kelas yang digunakan yaitu Model Kurt Lewin (Depdikbud, 1999: 20).

\section{HASIL DAN PEMBAHASAN}

Pada bab ini akan dikemukakan analisis data yang diperoleh dari hasil observasi dan hasil evaluasi pada setiap siklus yang telah direncanakan. Data yang diperolah berupa data kuantitatif dari hasil evaluasi dan data kualitatif yang dikumpulkan dari hasil observasi. Data kuantitatif yang diperoleh dari hasil evaluasi akan memberikan jawaban mengenai keberhasilan atau tidaknya proses pembelajaran dengan menerapkan model pembelajaran Round Table yang diukur dengan ketuntasan belajar secara klasikal. Data kualitatif diperoleh dari hasil observasi yang akan memberikan gambaran tentang aktivitas siswa yang merupakan hasil observer pada setiap pertemuan pelaksanaan proses pembelajaran. Berikut ini akan disajikan data hasil penelitian pada setiap siklus yang telah direncanakan.

\section{Siklus I \\ Perencanaan}

Pada tahap ini yang akan dilakukan adalah mempersiapkan semua kelengkapan penelitian baik berupa lembar observasi, instrument soal tes tulis, RPP dengan penerapan model pembelajaran Round Table baik untuk setiap siklus sesuai kebutuhan.

\section{Pelaksanaan Tindakan}

Dalam tahap pelaksanaan tindakan dilaksanakan kegiatan pembelajaran sesuai dengan rencana pelaksanaan pembelajaran yang telah dibuat. Untuk dapat menyesuaikan rencana pelaksanaan pembelajaran dalam penyampaian materi, termasuk didalamnya pembelajaran dengan menggunakan model pembelajaran Round Table untuk materi Klasifikasi Makhluk Hidup yang dilaksanakan 2 kali pertemuan untuk penyampaian materi dan 1 kali pertemuan untuk evaluasi. Proses pembelajaran siklus I dilaksanakan pada tanggal 9 Agustus 2021 dan 11 Agustus 2021 sedangkan evaluasi siklus I dilaksanakan pada tanggal 16 Agustus 2021.

\section{Observasi dan Evaluasi}

Hasil observasi diperoleh dari hasil pengamatan yang dilakukan oleh observer yang dilakukan pada setiap kali pertemuan pembelajaran dengan mengisi lembar observasi aktivitas 
Vol. 1 No. 3 Desember 2021 e-ISSN : 2797-3344 P-ISSN : 2797-3336

siswa untuk merekam jalannya proses pembelajaran. Berdasarkan hasil observasi terhadap aktivitas siswa setelah dianalisa diperoleh data sebagai berikut:

Tabel 1. Hasil Observasi Aktivitas Siswa Pada Siklus I

\begin{tabular}{cccccccccc}
\hline & \multicolumn{8}{c}{ Jumlah skor yang tampak } & \multicolumn{2}{c}{$\begin{array}{c}\text { Skor } \\
\text { Pertemuan }\end{array}$} & 1 & 2 & 3 & 4 & 5 & 6 & $\begin{array}{c}\text { Rata-rata } \\
\text { aktivitas }\end{array}$ & Kategori \\
Pertama & 2,3 & 2,6 & 2,3 & 2,3 & 2,3 & 2,3 & 14,4 & 2,35 & Kurang Aktif \\
Kedua & 3 & 2,6 & 3 & 2,6 & 3 & 3,3 & 17,5 & 2,92 & Cukup Aktif \\
\hline
\end{tabular}

Dari tabel di atas dapat dilihat bahwa aktivitas belajar siswa pada siklus I pertemuan 1 diperoleh rata-rata sebesar 2,35 dengan kategori Kurang Aktif dan pertemuan 2 diperoleh ratarata sebesar 2,92 dengan kategori Cukup Aktif.

Data tentang evaluasi hasil belajar siswa pada siklus I berdasarkan hasil evaluasi setelah dianalisis diperoleh data sebagai berikut:

Tabel 2. Hasil Evaluasi Belajar Siswa Pada Siklus I

\begin{tabular}{|c|c|c|c|c|c|}
\hline No. & Nama Siswa & $\mathbf{L} / \mathbf{P}$ & Skor & Nilai & $\begin{array}{c}\text { Tuntas(T)/Tidak } \\
\text { Tuntas(TT) } \\
\text { (KKM=75) }\end{array}$ \\
\hline 1 & Agung Bastian Samudra & $\mathrm{L}$ & 19 & 95 & TUNTAS \\
\hline 2 & Alfan Gunawan & $\mathrm{L}$ & 15 & 75 & TUNTAS \\
\hline 3 & Alfina Maurani & $\mathrm{P}$ & 18 & 90 & TUNTAS \\
\hline 4 & Annisa Dewi Putri & $\mathrm{P}$ & 17 & 85 & TUNTAS \\
\hline 5 & Ari Saputra & $\mathrm{L}$ & 16 & 80 & TUNTAS \\
\hline 6 & Arjuna Aedil Ringgo & $\mathrm{L}$ & 14 & 70 & TIDAK TUNTAS \\
\hline 7 & Arya Saputra & $\mathrm{L}$ & 13 & 65 & TIDAK TUNTAS \\
\hline 8 & Dewi Komala Sari & $\mathrm{P}$ & 14 & 70 & TIDAK TUNTAS \\
\hline 9 & Elsa Oktaviana & $\mathrm{P}$ & 16 & 80 & TUNTAS \\
\hline 10 & Fitria Ramdani & $\mathrm{P}$ & 15 & 75 & TUNTAS \\
\hline 11 & Fuzi Saputra & $\mathrm{L}$ & 13 & 65 & TIDAK TUNTAS \\
\hline 12 & Jannatul Jannah & $\mathrm{P}$ & 16 & 80 & TUNTAS \\
\hline 13 & Jhio Sastra Winarta & $\mathrm{L}$ & 17 & 85 & TUNTAS \\
\hline 14 & M. Ghazuwan Kamal & $\mathrm{L}$ & 15 & 75 & TUNTAS \\
\hline 15 & Maelani Citra Dewi & $\mathrm{P}$ & 18 & 90 & TIDAK TUNTAS \\
\hline \multicolumn{2}{|c|}{ Jumlah Nilai Seluruhnya } & \multicolumn{4}{|c|}{1180} \\
\hline \multicolumn{2}{|c|}{ Nilai Rata-rata } & \multicolumn{4}{|c|}{$\mathbf{7 8 , 6 7}$} \\
\hline \multicolumn{2}{|c|}{ Jumlah Siswa Yang Tuntas } & \multicolumn{4}{|c|}{15 siswa } \\
\hline \multicolumn{2}{|c|}{ Persentase Ketuntasan Klasikal } & \multicolumn{4}{|c|}{$66,7 \%$} \\
\hline
\end{tabular}

Dari tabel di atas dapat dilihat bahwa ketuntasan belajar secara klasikal yang dicapai sebesar $66,7 \%$ dengan nilai rata-rata sebesar 78,67. Hasil ini belum mencapai ketuntasan belajar secara klasikal sehingga pembelajaran dilanjutkan ke siklus berikutnya.

\section{Refleksi}

Berdasarkan analisis hasil observasi pada siklus I, jumlah siswa yang tuntas secara klasikal sebesar 66,7 \% berarti masih dibawah standar ketuntasan klasikal yang ditentukan. Oleh karena itu peneliti melanjutkan ke siklus berikutnya. Dalam siklus I ini terdapat kekurangan/kelemahan yang perlu untuk diperhatikan dan diperbaiki pada kegiatan siklus II diantaranya: 1) Siswa belum begitu aktif dalam proses pembelajaran, 2) Guru lebih memberikan kesempatan bagi siswa untuk aktif dalam pembelajaran dengan melibatkannya lebih maksimal, 3) Guru melaksanakan proses pembelajaran dengan menggunakan model pembelajaran Round Table dengan lebih maksimal sesuai sintak yang sudah disusun sehingga proses pembelajaran lebih berkualitas.

\section{Siklus II}

Proses pembelajaran pada siklus II diawali dengan pemberian umpan balik dari hasil evaluasi yang diberikan. Oleh karena itu, sebelum berdiskusi guru menghimbau agar siswa tidak ada yang ngobrol,mengganggu teman yang lainnya, dan tidak ada siswa yang diam 
Vol. 1 No. 3 Desember 2021 e-ISSN : 2797-3344 P-ISSN : 2797-3336

memperhatikan teman-temannya, demikian juga pembagian tugas dalam setiap kelompok harus lebih jelas sehingga siswa dapat melaksanakan tugasnya masing-masing.

\section{Perencanaan}

Pada tahap ini yang akan dilakukan adalah mempersiapkan semua kelengkapan penelitian baik berupa lembar observasi, instrument soal tes tulis, RPP dengan penerapan model pembelajaran Round Table baik untuk setiap siklus sesuai kebutuhan.

\section{Pelaksanaan Tindakan}

Dalam tahap pelaksanaan tindakan dilaksanakan kegiatan pembelajaran sesuai dengan rencana pelaksanaan pembelajaran yang telah dibuat. Untuk dapat menyesuaikan rencana pelaksanaan pembelajaran dalam penyampaian materi, termasuk didalamnya pembelajaran dengan menggunakan model pembelajaran Round Table untuk materi Klasifikasi Materi dan Perubahannya dilaksanakan dua kali pertemuan untuk penyampaian materi dan 1 kali pertemuan untuk evaluasi. Proses pembelajaran siklus II dilaksanakan pada tanggal 30 Agustus 2021 dan 1 September 2021 sedangkan evaluasi siklus II dilaksanakan pada tanggal 6 September 2021.

\section{Observasi dan Evaluasi}

Hasil observasi diperoleh dari hasil pengamatan yang dilakukan oleh observer yang dilakukan oleh rekan guru peneliti dengan mengisi lembar obervasi aktivitas siswa untuk merekam jalannya proses pembelajaran. Pada saat pembelajaran siklus II telah dilakukan perbaikan,dari hasil analisis obervasi aktivitas siswa pada siklus II didapat bahwa aktivitas siswa tergolong aktif dalam setiap pertemuan. Hal ini dapat dilihat pada tabel skor aktivitas siswa mengalami peningkatan dari pertemuan pertama ke pertemuan ke dua,seperti yang terlihat pada tabel di bawah ini.

Tabel 3 Hasil Observasi Aktivitas Siswa Pada Siklus II

\begin{tabular}{cccccccccc}
\hline Pertemuan & \multicolumn{1}{c}{ Jumlah skor yang tampak } & $\begin{array}{c}\sum \\
\text { Skor } \\
\text { aktivitas }\end{array}$ & $\begin{array}{c}\text { Rata- } \\
\text { rata } \\
\text { Aktivit }\end{array}$ & Kategori \\
Pertama & 1 & 2 & 3 & 4 & 5 & 6 & & as & \\
Kedua & 4,0 & 3,3 & 3,6 & 3,3 & 3,3 & 4,0 & 21,5 & 3,58 & Aktif \\
\hline
\end{tabular}

Dari tabel di atas dapat dilihat bahwa aktivitas belajar siswa pada siklus II pertemuan 1 diperoleh rata-rata sebesar3,58 dengan kategori Aktif dan pertemuan 2 diperoleh rata-rata sebesar 4,30 kategori Aktif. Data lengkap tentang evaluasi hasil belajar siswa pada siklus II berdasarkan hasil evaluasi pada siklus II setelah dianalisis diperoleh data sebagai berikut:

Tabel 4. Hasil Evaluasi Belajar Siswa Pada Siklus II

\begin{tabular}{|c|c|c|c|c|c|}
\hline No. & Nama Siswa & $\begin{array}{l}\mathbf{L} / \\
\mathbf{P}\end{array}$ & Skor & Nilai & $\begin{array}{c}\text { Tuntas(T)/Tidak } \\
\text { Tuntas(TT) } \\
(\text { KKM=75) }\end{array}$ \\
\hline 1 & Agung Bastian Samudra & $\mathrm{L}$ & 19 & 95 & TUNTAS \\
\hline 2 & Alfan Gunawan & $\mathrm{L}$ & 17 & 85 & TUNTAS \\
\hline 3 & Alfina Maurani & $\mathrm{P}$ & 15 & 75 & TUNTAS \\
\hline 4 & Annisa Dewi Putri & $\mathrm{P}$ & 16 & 80 & TUNTAS \\
\hline 5 & Ari Saputra & $\mathrm{L}$ & 15 & 75 & TUNTAS \\
\hline 6 & Arjuna Aedil Ringgo & $\mathrm{L}$ & 14 & 70 & TIDAK TUNTAS \\
\hline 7 & Arya Saputra & $\mathrm{L}$ & 17 & 85 & TUNTAS \\
\hline 8 & Dewi Komala Sari & $\mathrm{P}$ & 16 & 80 & TUNTAS \\
\hline 9 & Elsa Oktaviana & $\mathrm{P}$ & 13 & 65 & TIDAK TUNTAS \\
\hline 10 & Fitria Ramdani & $\mathrm{P}$ & 16 & 80 & TUNTAS \\
\hline 11 & Fuzi Saputra & $\mathrm{L}$ & 15 & 75 & TUNTAS \\
\hline 12 & Jannatul Jannah & $\mathrm{P}$ & 16 & 80 & TUNTAS \\
\hline 13 & Jhio Sastra Winarta & $\mathrm{L}$ & 16 & 80 & TUNTAS \\
\hline 14 & M.Ghazuwan Kamal & $\mathrm{L}$ & 17 & 85 & TUNTAS \\
\hline 15 & Maelani Citra Dewi & $\mathrm{P}$ & 18 & 90 & TUNTAS \\
\hline
\end{tabular}


Vol. 1 No. 3 Desember 2021 e-ISSN : 2797-3344 P-ISSN : 2797-3336

\begin{tabular}{lc}
\hline Jumlah Nilai Seluruhnya & 1200 \\
Nilai Rata-rata & $\mathbf{8 0 , 0 0}$ \\
Jumlah Siswa Yang Tuntas & 13 \\
Persentase Ketuntasan Klasikal & $\mathbf{8 6 , 6 7 \%}$ \\
\hline
\end{tabular}

Dari tabel di atas dapat dilihat bahwa ketuntasan belajar secara klasikal yang dicapai sebesar 86,67 \% dengan nilai rata-rata sebesar 80,00. Hasil ini telah mencapai ketuntasan belajar secara klasikal sehingga pembelajaran dalam penelitian ini tidak dilanjutkan dengan siklus berikutnya.

\section{Refleksi}

Berdasarkan analisis hasil observasi pada siklus II, jumlah siswa yang tuntas secara klasikal sebesar $86,67 \%$ berarti sudah memenuhi standar ketuntasan klasikal yang ditentukan. Oleh karena itu peneliti menghentikan penelitian ke siklus berikutnya sesuai perencanaan.

\section{Pembahasan}

Penelitian tindakan kelas ini dilaksanakan sebagai upaya untuk meningkatkan Prestasi Belajar IPA pada siswa kelas VII D semester ganjil dengan melaksanakan pembelajaran menggunakan model Pembelajaran Round Table di SMP Negeri 2 Pringgabaya Tahun Pembelajaran 2021/2022.

Berdasarkan hasil analisis data pada tiap siklus, terlihat bahwa hasil dari siklus I ke siklus II mengalami peningkatan. Pada pelaksanaan pembelajaran dan hasil analisis data siklus I, untuk aktivitas siswa diperoleh nilai rata-rata sebesar 2,63 dan aktivitas siswa pada siklus II diperoleh nilai rata-rata kelas sebesar 3,94. Terkait dengan hasil ulangan pada siklus I dan II dapat dilihat rinciannya dibawah ini.

Tabel 5 Ringkasan Hasil Evaluasi Pada Siklus I

\begin{tabular}{llc}
\hline No & \multicolumn{1}{c}{ Uraian } & Hasil \\
1 & Nilai Terendah & 65 \\
2 & Nilai Tertinggi & 95 \\
3 & Rata-rata & 78,67 \\
4 & Jumlah siswa yang tuntas & 10 \\
5 & Jumlah siswa yang ikut tes & 15 \\
6 & Persentase Ketuntasan Kalsikal & $66,7 \%$ \\
\hline
\end{tabular}

Sedangkan pada siklus II hasilnya sebagai berikut:

Tabel 6 Ringkasan Hasil Evaluasi Pada Siklus II

\begin{tabular}{llc}
\hline No & \multicolumn{1}{c}{ Uraian } & Hasil \\
1 & Skor Terendah & 65 \\
2 & Skor Tertinggi & 95 \\
3 & Rata-rata & 80,00 \\
4 & Jumlah siswa yang tuntas & 13 \\
5 & Jumlah siswa yang ikut tes & 15 \\
6 & Persentase Ketuntasan Klasikal & $86,67 \%$ \\
\hline
\end{tabular}

Setelah melihat kedua tabel hasil evaluasi dari siklus I dan II dimana nilai yang mereka peroleh sudah mencapai tingkat ketuntasan belajar. Dan melebihi tingkat ketuntasan belajar secara klasikal.

\section{KESIMPULAN}

Berdasarkan hasil penelitian dan pembahasan diatas, dapat di simpulkan bahwa model pembelajaran Round Table dapat meningkatkan aktivitas dan prestasi belajar siswa pada materi Klaifikasi Makhluk Hidup dan Klasifikasi Materi dan Perubahannya di kelas VII D SMP Negeri 2 Pringgabaya pada semester ganjil tahun pelajaran 2021/20202 Peningkatan tersebut dapat 
Vol. 1 No. 3 Desember 2021 e-ISSN : 2797-3344 P-ISSN : 2797-3336

dilihat dari perolehan nilai skor aktivitas siswa, aktivitas guru dan nilai rata-rata kelas serta tingkat ketuntasan secara klasikal pada tiap siklus mengalami peningkatan baik pada siklus I maupun siklus II.

Dari hasil penelitian dan pembahasan di atas dapatlah kami simpulkan bahwa Penerapan model pembelajaran Round Table dapat meningkatkan Prestasi Belajar IPA pada siswa kelas VII D SMP Negeri 2 Pringgabaya pada masa Pandemi Covid-19 Tahun Pelajaran 2021/2022.

\section{DAFTAR PUSTAKA}

Abidin, A. Z. (2019). Meningkatkan Kompetensi Guru IPA dalam Penggunaan Metode Round Table melalui Pembinaan Terbimbing di SMPN 3 Masbagik. NUSANTARA, 1(3), 212237.

Annurwanda, P., \& Friantini, R. N. (2019). Efektivitas Penerapan Metode Round Table Dan Ekspositori Terhadap Prestasi Belajar Matematika Ditinjau Dari Kemampuan Awal. Riemann: Research of Mathematics and Mathematics Education, 1(1), 1-13.

Budayani, I. (2016). Penerapan Metode Pembelajaran Round Table Untuk Meningkatkan Hasil Belajar Bahasa Inggris Pada Siswa Kelas Viii-5 Smp Negeri 30 Pekanbaru Tahun Pelajaran 2015/2016. Suara Guru, 1(1), 41-54.

Fauzi, M. I. (2016). Hubungan Kedisiplinan Belajar di Rumah dan Di Sekolah dengan Prestasi Belajar IPA Siswa Kelas IV Sd Se-Gugus Dewi Sartika UPPD Tegal Selatan Kota Tegal 2012/2013. Dinamika Jurnal Ilmiah Pendidikan Dasar, 8(1).

Harefa, D. (2020). Peningkatan Prestasi Belajar IPA Siswa Pada Model Pembelajaran Learning Cycle Dengan Materi Energi dan Perubahannya. Trapsila: Jurnal Pendidikan Dasar, 2(01), 25-36.

Muhajir, S., \& Rohaeti, E. (2015). Perbedaan penerapan model pembelajaran STS dan CTL terhadap literasi sains dan prestasi belajar IPA. Jurnal Pendidikan Matematika dan Sains, 3(2), 143-155.

Ratnasari, S. C. (2013). Efektivitas Model Pembelajaran Kooperatif Tipe Round Table dalam Meningkatkan Keterampilan Menulis Siswa (Doctoral dissertation, Universitas Pendidikan Indonesia).

Retariandalas, R. (2017). Pengaruh minat membaca dan motivasi belajar terhadap prestasi belajar IPA siswa. Formatif: Jurnal Ilmiah Pendidikan MIPA, 7(2).

Susilowati, S. (2017). Pengembangan bahan ajar IPA terintegrasi nilai Islam untuk meningkatkan sikap dan prestasi belajar IPA siswa. Jurnal Inovasi Pendidikan IPA, 3(1), 78-88.

Susiani, K., Dantes, N., \& Tika, N. (2013). Pengaruh model pembelajaran quantum terhadap kecerdasan sosio-emosional dan prestasi belajar IPA siswa kelas V SD di Banyuning (Doctoral dissertation, Ganesha University of Education).

Syah, D. N., Amin, A., \& Gumay, O. P. U. (2019). Hubungan motivasi belajar terhadap prestasi belajar IPA terpadu. SPEJ (Science and Physic Education Journal), 2(2), 66-71. 